\title{
Keberagaman Gender Dewan Komisaris dan Direksi terhadap Kinerja Perusahaan
}

\author{
Sinye Polani Thoomaszen ${ }^{1}$ \\ Fakultas Ekonomi dan Bisnis \\ Universitas Airlangga, Indonesia
}

\author{
Widi Hidayat ${ }^{2}$ \\ Fakultas Ekonomi dan Bisnis \\ Universitas Airlangga, Indonesia
}

\begin{abstract}
Surel : shinyepolani@gmail.com
ABSTRAK

Penelitian bertujuan untuk melihat pengaruh dari keberagaman gender dewan komisaris dan direksi terhadap kinerja keuangan perusahaan. Sampel yang digunakan dalam penelitian ini yaitu perusahaan property dan kesehatan yang terlisting dalam Bursa Efek Indonesia periode 2015-2018 dengan total 30 perusahaan. Metode yang dipakai adalah metode kuantitatif dengan menggunakan analisis regresi data panel. Hasil penelitian menunjukkan bahwa keragaman gender dewan komisaris tidak memiliki efek positif pada kinerja perusahaan sedangkan keragaman gender dewan direksi memiliki efek negatif pada kinerja perusahaan. Variabel ukuran perusahaan dan direktur independen sebagai variabel kontrol juga menunjukkan pengaruh yang signifikan terhadap kinerja perusahaan. Untuk penelitian selanjutnya, direkomendasikan untuk menggunakan dua metode lainnya seperti dummy atau proporsi gender untuk mengukur keragaman gender sehingga hasilnya dapat dibandingkan, serta data penelitiannya lebih diperbanyak lagi.
\end{abstract}

Kata Kunci: Keberagaman Gender; Kinerja Perusahaan; Ukuran Perusahaan; Direktur Independen.

\section{Board Gender Diversity and Firm Performance}

\begin{abstract}
This study examined the influence of board gender diversity on the firm performance.the research sample use property and health companies listed in Indonesia stock exchange 2015-2018. total 30 companies. use quantitative methodology with panel regression data analysis techniques were used in this study. The results showed that the gender diversity of the board of commissioners did not have a positive effect on company performance (H1 was rejected) while the gender diversity of the board of directors had a negative effect on company performance (H2 rejected). SIZE and ID control variables also showed significant effect on company performance. For further research it is recommended to use two other methods such as Dummy or gender proportion to measure gender diversity so that the results can be compared, as well as more research data.

Keywords: Board Gender Diversity; Firm Performance; Size; Independen Director.
\end{abstract}

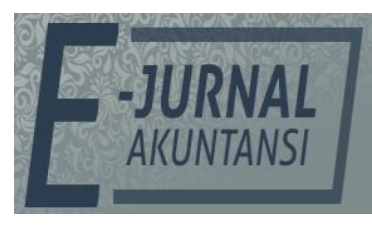

e-ISSN 2302-8556

Vol. 30 No. 8

Denpasar, Agustus 2020

Hal. 2040-2052

DOI:

10.24843/EJA.2020.v30.i08.p11

PENGUTIPAN:

Thoomaszen, S.P. \& Hidayat,

W. (2020). Keberagaman

Gender Dewan Komisaris dan Direksi terhadap Kinerja Perusahaan. E-Jurnal Akuntansi, 30(8), 2040-2052

RIWAYAT ARTIKEL: Artikel Masuk: 18 Mei 2020 Artikel Diterima: 5 Agustus 2020

Artikel dapat diakses : https://ojs.unud.ac.id/index.php/Akuntansi/index 


\section{PENDAHULUAN}

Diversity (keberagaman) dalam perusahaan saat ini dipandang sebagai suatu tolak ukur apakah Good Corporate Governance dalam perusahaan tersebut efektif dan efisien atau sebaliknya (Lückerath-Rovers, 2013). Keberagaman dalam dewan komisaris dan dewan direksi dapat diklasifikasikan dari segi usia, etnis, dan jenis kelamin. Keberagaman dewan komisaris dan dewan direksi juga diimbangi dengan keberagaman kepemilikan, pengalaman, latar belakang pendidikan, dan status sosial ekonomi. Keberagaman yang masih sampai dengan saat ini menarik untuk diteliti yaitu terkait dengan keberagaman gender dalam manajemen puncak perusahaan.

Isu terkait gender saat ini merupakan isu yang sedang banyak diteliti oleh para peneliti terlebih di Indonesia. Terlebih lagi keberadaan serta peran gender wanita dalam perusahaan memberikan dampak yang positif terhadap kinerja perusahaan. Gender wanita dalam perusahaan terlebih dalam manajemen eksekutif seperti dewan komisaris dan dewan direksi di Indonesia belum diharuskan ataupun di tetapkan berapa persen kedudukan wanta dalam dewan perusahaan, tetapi beberapa perusahaan saat ini mulai perlahan-lahan memberikan kedudukan tersebut kepada wanita walaupun belum terdapat regulasi yang mengatur terkait keberadaan wanita dalam perusahaan (Ionascu et al., 2018), (Lückerath-Rovers, 2013), (Pasaribu, 2019), dan (Terjesen et al., 2016).

Tidak seperti di Indonesia, keberagaman gender dalam perusahaan dibeberapa negara seperti Eropa dan US bukan lagi suatu hal yang dianggap tidak pantas, bahkan di Eropa sendiri khususnya di Negara Norwegia mengeluarkan regulasi terkait berapa persen kedudukan wanita dalam perusahaan. Norwegia menetapkan $40 \%$ kursi anggota dewan harus diduduki oleh wanita, kemudian di ikuti oleh Negara Spayol yang juga mengeluarkan regulasi terkait kedudukan wanita dalam dewan perusahaannya (Ionascu et al., 2018).

Berdasarkan penelitian yang dilakukan oleh Centre for Governance, Institutions and Organisations menunjukkan bahwa pada tahun 2012 kedudukan perempuan dalam manajemen eksekutif perusahaan yang terdaftar di Indonesian Stock Exchange (IDX) adalah sebesar 11,6\%. Kemudian pada tahun 2015 kedudukan perempuan sebesar 11,1 persen. Indonesia juga selama 4 tahun berturut-turut menempati posisi kelima seasia pasifik dengan jumlah perempuan dalam perusahaan yang terdaftar dalam IDX. Jumlah di Indonesia mengalahkan negara-negara lain seperti Hongkong $(10.7 \%)$, India $(8,6 \%)$, Singapura $(7,7 \%)$, Jepang $(3,3 \%)$, dan Korea $(2,6 \%)$ Di Indonesia, tenaga kerja antara pria dan wanita relatif sama. Namun, kehadiran perempuan di ruang dewan hanya $6 \%$, angka ini jauh lebih rendah daripada negara-negara di Eropa dan AS di mana anggota direksi perempuan masing-masing sekitar 17 persen dan 15 persen (Dieleman et al., 2016), dan (Dieleman et al., 2015). Hal ini menunjukkan bahwa keberadaan perempuan dalam manajemen puncak perusahaan di Indonesia mulai meningkat sedikit demi sedikit.

Peran wanita dalam perusahaan sangat memberikan dampak yang besar terhadap perusahaan, dimana dengan adanya wanita dapat membantu proses peningkatan kinerja perusahaan. Berdasarkan penelitian yang dilakukan oleh beberapa peneliti menjelaskan bahwa sifat kehati-hatian serta teliti yang dimiliki 
oleh wanita membantu perusahaan meningkatkan kinerjanya, dimana wanita dengan sifatnya tersebut sangat menghindari resiko-resiko yang tinggi serta lebih memilih resiko yang lebih kecil dan aman bagi perusahaan. Sehingga perusahaan yang memiliki angota dewan perusahaan wanita sangat membantu menetralisir sifat anggota pria yang cenderung senang mengambil resiko yang tinggi bagi perusahaan (Abdullah, 2014), (Ramadhani \& Adhariani, 2015), (Wiley \& Monllor-Tormos, 2018).

Keberagaman gender dalam perusahaan sendiri saat ini selain membantu dalam meningkatkan kinerja perusahaan, dapat juga meminimalisir agency problem yang terjadi dalam perusahaan. Dalam teori agensi dijelaskan bahwa antara prinsipal atau pemilik perusahaan dengan agen atau manajer perusahaan terjadi perbedaan kepentingan, dimana agen lebih mementingkan kepentingan pribadinya dibandingkan kepentingan dan tujuan perusahaan. Dalam kerangka ini, dewan yang beraneka ragam gender bertindak sebagai kontrol yang lebih baik karena jangkauan pandangan dan pendapat yang lebih luas dapat meningkatkan independensi dewan. Keberagaman gender dapat menjadi mekanisme dalam membantu mengurangi agensi problem. Masalah agensi dapat dikurangi atau ditekan dengan tata kelola perusahaan yang kuat, sehingga dengan hal tersebut dapat membantu perusahaan meningkatkan kinerja perusahaannya (Hamdani \& Hatane, 2015), (Ionascu et al., 2018), (Isidro \& Sobral, 2015), (Luckerath-Rovers, 2013), dan (Terjesen et al., 2016).

Penelitian yang dilakukan oleh Sial et al.,(2018) dan Terjesen et al., (2016) menunjukkan hasil bahwa keberagaman gender dalam perusahaan memberikan pengaruh positif terhadap kinerja perusahaan. Hal ini menunjukkan bahwa peran wanita dalam perusahaan dapat membantu meminimalisir sifat pria yang cenderung suka mengambil resiko yang tinggi bagi perusahaan. Sedangkan menurut penelitian yang dilakukan oleh Abdullah, (2014), Chapple \& Humphrey, (2014), dan Ramadhani \& Adhariani, (2015) menunjukkan bahwa keberagaman gender dalam manajemen puncak perussahaan tidak berpengaruh terhadap kinerja perusahaan. Hal ini menunjukkan bahwa dengan ada ataupun tidak wanita dalam perusahaan tidak memberikan dampak yang signifikan terhadap kinerja perusahaan. Berdasarkan hasil penelitian terdahulu masih menunjukkan adanya ketidakkonsistenan hasil antara keberagaman gender dan kinerja perusahaan. Sehingga penelitian ini mencoba untuk mengkaji lagi hubungan antara keberagaman gender dan kinerja perusahaan.

Populasi yang dipakai dalam penelitian ini yaitu perusahaan sektor property dan real estate dan sektor kesehatan yang terdaftar dalam IDX (Indonesian Stock Exchange). Pemilihan populasi penelitian ini berdasarkan pada penelitian yang dilakukan oleh Dieleman et al., $(2016,2015)$ yang menunjukkan bahwa sektor property dan kesehatan yang memiliki jumlah wanita lebih banyak dibandingkan sektor yang lain. Analisis data yang digunakan dalam penelitian ini yaitu regresi linear dengan diuji menggunakan STATA.

Teori keagenan menjelaskan bahwa dalam perusahaan terjadi perbedaan kepentingan antara principal dan agen yang dapat menyebabkan terjadinya masalah agensi. Menurut Jensen \& Meckling (1976) perusahaan merupakan kumpulan kontrak (nexus of contract) antara pemilik sumber daya ekonomis (principal) dan manajer (agent) yang mengurus penggunaan dan pengendalian 
sumber daya tersebut. Masalah agensi ini terjadi ketika agen dalam perusahaan yakni manajemen lebih mementingkan kepentingan pribadinya dibandingkan kepentingan perusahaan, dan hal tersebut dapat merugikan perusahaan (Shogren et al., 2017). Salah satu cara menyeimbangkan atau meminimalisir masalah agensi dalam perusahaan yaitu dengan meningkatkan kualitas tata kelola perusahaan. Untuk meningkatkan kualitas tata kelola perusahaan salah satunya dengan adanya board diversity dalam perusahaan, dengan adanya board diversity ini dapat meningkatkan kualitas pemantauan serta kontroling dalam perusahaan, karena semakin beragam anggota dewan perusahaan dapat meningkatkan independensi dewan. Hal ini menunjukkan bahwa dengan anggota dewan yang beragam dapat menyelesaikan masalah agensi dengan cara dan pandangan yang berbeda (Darmadi, 2011).

Dalam teori agensi dapat diasumsikan bahwa dengan adanya wanita dalam anggota dewan perusahaan dapat membuat dewan perusahaan lebih mandiri dan efektif dalam mengawasi para manajer perusahaan. Namun seringkali kehadiran wanita dalam dewan perusahaan seringkali disingkirkan dari kegiatan-kegiatan penting perusahaan, hal inilah yang dapat berdampak pada kinerja perusahaan, karena dengan dibatasinya kegiatan yang dapat diikuti oleh wanita dalam mengakibatkan perusahaan kehilangan nilai-nilai potensial dari anggota wanita. Dimana nilai-nilai potensial tersebut sangat membantu dalam proses pengawasan serta kontroling terhadap manajer perusahaan (Ionascu et al., 2018), (Lückerath-Rovers, 2013) dan (Terjesen et al., 2016).

Keragaman gender sangat berkaitan dengan lingkungan kerja saat ini, dalam hal ini pria dan wanita dipekerjakan pada tingkat yang sama, dibayar dengan gaji yang sama dengan pekerjaan yang sama, dan dipromosikan pada tingkat yang sama. Keragaman gender sangat penting bagi tempat kerja manapun.hal ini karena pria dan wanita memiliki sudut pandang, ide, dan wawasan pasar yang berbeda, yang memungkinkan penyelesaian masalah yang lebih baik (Ionascu et al., 2018), (Low et al., 2015), dan (Wahid, 2018).

Studi yang dilakukan oleh Gallup menemukan bahwa mempekerjakan tenaga kerja yang beragam secara demografis dapat meningkatkan kinerja keuangan perusahaan. Penelitian juga menjelaskan bahwa tim yang beraneka ragam gender memiliki kinerja yang lebih baik daripada tim satu gender, karena pria dan wanita memiliki sudut pandang, ide, dan wawasan pasar yang berbeda, seperti yang telah dijelaskan.Tenaga kerja yang beragam gender menyediakan akses yang lebih mudah ke sumber daya, seperti berbagai sumber kredit, berbagai sumber informasi, dan pengetahuan industry yang lebih luas. Tenaga kerja yang beragam gender juga memungkinkan perusahaan untuk melayani basis pelanggan yang semakin beragam juga. Keragaman gender membantu perusahaan menarik dan mempertahankan wanita berbakat. Untuk alasan ini dan lainnya, maka masuk akal bagi bisnis untuk menjadikan keragaman gender sebagai prioritas (Isti \& Adhariani, 2017), (Lückerath-Rovers, 2013) dan (Terjesen et al., 2016).

Argument terkait pengaruh keragaman gender dalam manajemen puncak terhadap kinerja perusahaan sangat beragam. Beberapa memberikan hasil yang mendukung bahwa keragaman gender memberikan dampak positif terhadap kinerja perusahaan, sedangkan beberapa penelitian lain membantah bahwa 
keragaman gender tidak selamanya dapat membantu kinerja perusahaan. Hal ini yang masih menjadi polemik dalam penelitiam terkait dengan keragaman gender dalam manajemen puncak (Ionascu et al., 2018), (Isti \& Adhariani, 2017), (Kilic \& Kuzey, 2016), dan (Sial et al., 2018).

Keragaman gender pada manajemen puncak memberikan dampak yang positif jika di terapkan, selain meningkatkan kualitas tata kelola perusahaan, keragaman gender ini juga dapat memberikan dampak positif terhadap kinerja perusahaan, serta dengan keragaman gender ini bisa meminimalisir masalah agensi yang terjadi dalam perusahaan. Beberapa penelitian memberikan hasil yang mendukung argument tersebut, dimana dengan keragaman gender memberikan beberapa keuntungan yang dapat bisa memakmurkan perusahaan. Alasan mengapa diperlukan keragaman gender dalam perusahaan yaitu, adanya perbedaan perspektif antara pria dan wanita yang dapat memberikan inovasi serta memicu kreativitas yang dapat membantu perusahaan menemukan dan menangkap peluang baru (Ionascu et al., 2018), (K1lıc \& Kuzey, 2016), (LückerathRovers, 2013), (Mensi-Klarbach, 2014) dan (Terjesen et al., 2016).

Hukum korporasi di Indonesia mengadopsi struktur dewan perusahaan dua tingkat atau two tier. Jenis struktur dewan ini juga di adopsi di negaranegara seperti Jerman, Belanda, dan Jepang. Perusahaan harus memiliki dua dewan dalam struktur organisasinya, yaitu dewan komisaris dan dewan direksi. Anggota dewan komisaris dan dewan direksi dipilih oleh pemegang saham dalam rapat umum pemegang saham. Dewan direksi memilki peran dalam keberlangsungan manajemen perusahaan dan dipimpin oleh seorang presiden direktur, serta bertanggungjawab kepada pemegang saham dan dewan komisaris. Dewan komisaris yang diketuai oleh presiden komisaris mewakili pemegang saham dan melakukan peran pengawasan terhadap manajemen. Oleh karena itu fungsi dewan komisaris hanyalah non-eksekutif. Anggotanya dapat berafiliasi dengan perusahaan (tidak independen) atau dari luar perusahaan (independen). Setiap dewan komisaris dan dewan direksi memiliki anggota sendiri, sehingga keanggotaan yang tumpeng tindih tidak diizinkan. Sehingga dalam struktur two tier tidak ada peran dualitas (Darmadi, 2011), (Fathonah, 2018), (Ionascu et al., 2018), dan (Lückerath-Rovers, 2013).

Penelitian terkait keberagaman gender dalam manajemen puncak terhadap kinerja keuangan masih menunjukkan hasil yang tidak konsisten. Oleh karena itu penelitian ini dilakukan lagi untuk melihat apakah keragaman gender dalam manajemen puncak memberikan hasil yang posditif terhadap kinerja perusahaan.

Seperti yang sudah dijelaskan sebelumnya bahwa peran dewan komisaris maupun dewan direksi dalam menjalankan perusahaan sangat berbeda. Dalam konteks dewan komisaris yang bertugas mengawasi jalannya perusahaan terutama mengawasi bagaimana dewan direksi dalam menjalankan tugasnya merupakan suatu komponen penting yang dapat membantu dalam peningkatan kinerja keuangan perusahaan, dengan adanya keberagaman gender dalam dewan komisaris bisa membantu meningkatkan kinerja perusahaan semakin membaik, dimana dengan beragamnya gender dalam dewan komisaris dapat saling melengkapi kekurangan masing-masing anggota baik itu wanita maupun pria. Sehingga dalam proses pengawasan terhadap dewan direksi lebih 
maksimal dibandingkan tidak ada wanita sama sekali dalam struktur dewan komisaris (Bart \& McQueen, 2013), (Mensi-Klarbach, 2014), dan (Wiley \& Monllor-Tormos, 2018).

$\mathrm{H}_{1}$ : Keberagaman gender dalam dewan komisaris berpengaruh positif terhadap kinerja perusahaan.

Seperti yang sudah dijelaskan dalam penjelasan sebelumnya bahwa antara pria dan wanita memiliki sifat yang berbeda dalam menjalankan tugas sebagai dewan direksi. Pria cenderung mengambil resiko yang tinggi dan berbahaya bagi kelangsungan perusahaan, sedangkan wanita cenderung mengambil resiko yang aman dalam proses menjalankan tugas sebagai dewan direksi. Dengan adanya keberagaman gender dalam dewan direksi sangat membantu meminimalisir sifat pria yang cenderung mengambil resiko yang tinggi dan berbahaya bagi perusahaan. Wanita dalam dewan direksi mampu meminimalisir resiko dan berhati-hati dalam pengambilan keputusan yang pada akhirnya hal ini dapat membantu perusahaan survive dan dapat menghasilkan kinerja perusahaan yang baik (Chapple \& Humphrey, 2014), (Isti \& Adhariani, 2017), (Ramadhani \& Adhariani, 2015) dan (Wiley \& Monllor-Tormos, 2018).

$\mathrm{H}_{2}$ : Keberagaman gender dalam dewan direksi berpengaruh positif terhadap kinerja perusahaan.

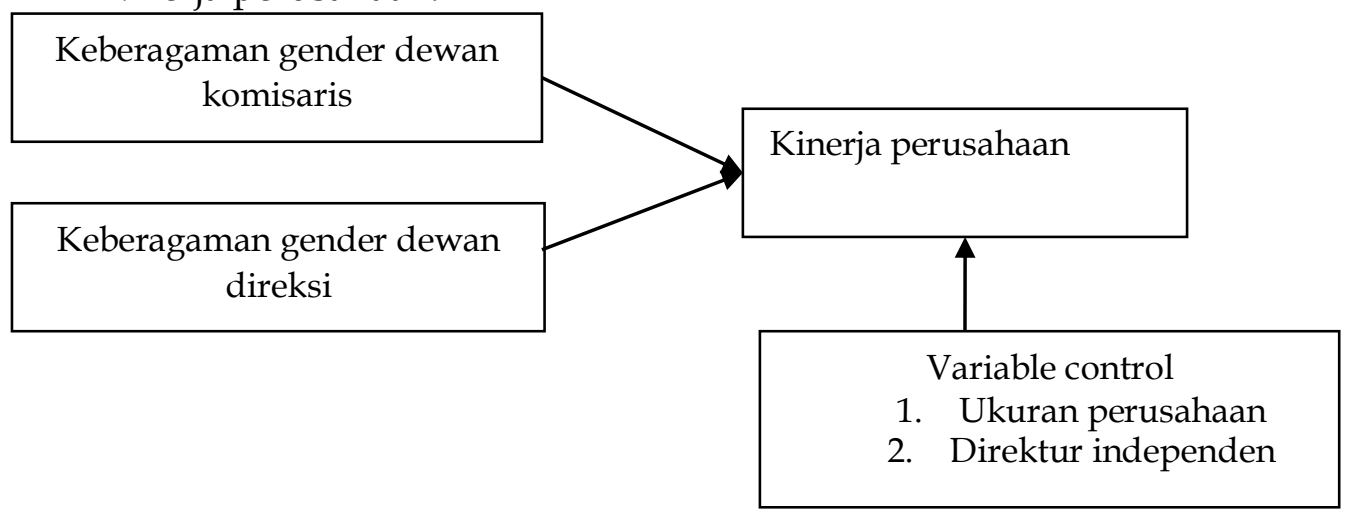

Sumber: Data Penelitian, 2020

\section{Gambar 1. Model Peneltian}

\section{METODE PENELITIAN}

Dalam penelitian ini peneliti menggunakan dua variabel kontrol yaitu ukuran perusahaan dan direktur independen. Variabel kontrol ini digunakan untuk memaksimalkan hasil penelitian sehingga hasil variabel independen tidak dipengaruhi oleh faktor luar yang tidak diteliti dalam penelitian ini. Terkait dengan variabel kontrol yang dipilih, peneliti menggunakan dua variabel ini dengan melihat hasil yang konsisten terkait ukuran perusahaan dan direktur independen terhadap kinerja dalam penelitian terdahulu.

Metode penelitian yang digunakan dalam penelitian ini adalah kuantitatif. Penelitian kuantitatif adalah penelitian dalam proses menggunakan angka mulai dari pengumpulan data sampai dengan interpretasi data dalam hasil penelitian. Jenis data yang digunakan dalam penelitian ini adalah jenis data kuantitatif dengan diukur skala numerik dalam bentuk nominal, ordinal, dan rasio. Data penelitian ini merupakan jenis data sekunder. Metode pengumpulan 
data archival digunakan melalui pengunduhan laporan keuangan serta laporan tahunan yang berasal dari laman Bursa Efek Indonesia (idx.co.id).

Populasi yang digunakan dalam penelitian ini adalah semua perusahaan property dan real estate serta perusahaan kesehatan yang terdaftar dalam Bursa Efek Indonesei (BEI). Kedua sektor perusahaan tersebut dipilih karena kedua sektor tersebut yang memiliki keragaman gender dalam manajemen puncak lebih banyak dibandingkan dengan sektor lainnya, sehingga peneliti ingin focus terhadap sektor yang memiliki keragaman gender lebih banyak dari sektor lainnya (Dieleman et al., 2016, 2015). Metode pemilihan sampel yang digunakan dalam pemilihan sampel dalam penelitian ini adalah purposive sampling, yaitu metode pemilihan objek dengan kriteria tertentu (Sugiyono, 2014).

Purposive sampling digunakan untuk mendapatkan sampel penelitian yang dapat menggambarkan populasi penelitian secara keseluruhan. Kriteria pemilihan sampel adalah perusahaan property dan real estate serta perusahaan kesehatan yang terdaftar di Bursa Efek Indonesia pada periode 2015-2018; perusahaan property dan real estate serta perusahaan kesehatan yang menerbitkan laporan tahunan dalam periode 2015-2018. Regresi panel digunakan dalam penelitian ini untuk menguji hipotesis penelitian dengan menggunakan STATA sebagai alat pengujian.

Tabel 1. Kriteria Sampel Penelitian

\begin{tabular}{ll}
\hline Kriteria & Total \\
\hline Perusahaan property dan real estate terdaftar di BEI & 65 \\
Perusahaan property dan real estate terdaftar di BEI periode 2015-2018 & 46 \\
Perusahaan kesehatan terdaftar di BEI & 17 \\
$\begin{array}{l}\text { Perusahaan kesehatan terdaftar di BEI periode 2015-2018 } \\
\text { Perusahaan property dan real estate yang menerbitkan laporan tahunan }\end{array}$ & 18 \\
2015-2018 & 12 \\
$\begin{array}{l}\text { Perusahaan kesehatan yang menerbitkan laporan tahunan 2015-2018 } \\
\text { Jumlah perusahaan yang diteliti }(18+12=30 \text { perusahaan } \times 4 \text { tahun } \\
\text { periode penelitian) }\end{array}$ & 120 \\
\hline Sumber: Sugiyono, 2014 &
\end{tabular}

\section{HASIL DAN PEMBAHASAN}

Uji statistic deskriptif digunakan untuk menganalisis serta menggambarkan data yang telah dikumpulkan dalam penelitian. Statistik deskriptif memberikan deskripsi terkait nilai rata-rata (mean), median, minimum dan maksimum dari data yang telah dikumpulkan. Hasil statistik deskriptif menunjukkan nilai ROA maksimum 0,35 yang dimiliki oleh PT Fortune Mate Indonesia Tbk di tahun 2016 dan nilai minimum -0,076 yang dimiliki oleh PT Sejahteraraya Anugrah jaya Tbk di tahun 2015. Nilai rata-rata ROA sebesar 0,04 dan median sebesar 0,04. Variabel X1 BLAUDDKOM atau keragaman gender dewan komisaris memiliki nilai maksimum sebesar 0,5 dimiliki oleh PT Tempo Scan Pacific Tbk di tahun 2015 dan nilai minimum sebsar 0 dimiliki oleh PT Industri Jamu dan Farmasi Sido Muncul Tbk di tahun 2015. Nilai rata-rata BLAUDKOM sebesar 0,23 dan median sebesar 0,28. Variabel X2 BLAUDDIR atau keragaman gender dewan direksi memiliki nilai maksimum sebesar 0,5 dimiliki oleh PT Bukit Darmo Property Tbk di tahun 2015 dan nilai minimum sebesar 0 dimiliki oleh PT Modernland Realty 
Ltd Tbk di tahun 2015. Nilai rata-rata BLAUDDIR sebesar 0.26 dan median sebesar 0,32 .

Tabel 2. Statistik Deskriptif

\begin{tabular}{lllll}
\hline Variabel & MEAN & MEDIAN & MIN & MAX \\
\hline ROA & 0.04 & 0.04 & -0.076 & 0.35 \\
BLAUDKOM & 0.23 & 0.28 & 0 & 0.5 \\
BLAUDDIR & 0.26 & 0.32 & 0 & 0.5 \\
SIZE & 28.92 & 28.90 & 25.79 & 31.58 \\
ID & 0.19 & 0.20 & 0 & 0.5 \\
\hline
\end{tabular}

Sumber: Data Penelitian, 2020

Variabel X3 SIZE atau ukuran perusahaan memiliki nilai maksimum sebesar 31,58 dimiliki oleh PT Bumi Serpong Damai Tbk di tahun 2018 dan nilai minimum sebesar 25,79 dimiliki oleh PT Pyridam Farma Tbk di tahun 2017. Nilai rata-rata SIZE sebesar 28,92 dan median 28,90. Variabel X4 ID atau direktur independen memiliki nilai maksimum sebesar 0,5 dimiliki oleh PT Pyridam Farma Tbk di tahun 2017 dan nilai minimum sebesar 0 dimiliki oleh PT Bukit Darmo Property Tbk di tahun 2018. Nilai rata-rata ID sebesar 0,19 dan median 0,20 .

Tabel 3. Pearson Correlation

\begin{tabular}{llllll}
\hline & ROA & BLAUDKOM & BLAUDDIR & SIZE & ID \\
\hline ROA & 1.0000 & & & & \\
BLAUDKOM & -0.0248 & 1.0000 & & & \\
& $(0.7882)$ & & & & \\
BLAUDDIR & -0.1507 & 0.0680 & 1.0000 & & \\
& $(0.1004)$ & $(0.4608)$ & & & \\
SIZE & 0.0908 & 0.0209 & -0.0674 & 1.0000 & \\
& $(0.2242)$ & $(0.8206)$ & $(0.4647)$ & & \\
ID & 0.1442 & 0.1266 & 0.0698 & $-0.3822^{* * *}$ & 1.0000 \\
& $(0.1161)$ & $(0.1681)$ & $(0.4486)$ & $(0.0000)$ & \\
\hline
\end{tabular}

Sumber: Data Penelitian, 2020

$p$-values in parentheses * $p<0.1,{ }^{* *} p<0.05,{ }^{* * *} p<0.01$

Pearson Correlation digunakan untuk menguji hubungan antar variabel. Tabel 3, menunjukkan hasil dari uji pearson correlation antar variabel dalam penelitian ini. Variabel SIZE memiliki nila korelasi sebesar 0,0908 dengan nilai signifikan sebesar 0,2242. Variabel ID memiliki nilai korelasi sebesar 0,14442 dengan nilai signifikansi sebesar 0,1161. Berdasarkan hasil pengujian pearson correlatin menunjukkan bahwa variabel SIZE dan ID memiliki korelasi yang kuat terhadap ROA.

Tabel 4, menunjukkan hasil regresi panel data menggunakan model Pooled Least Square (PLS), Fixed Effect (FE), dan Random Effects (RE). berdasarkan hasil dari ketiga model tersebut menunjukkan bahwa model PLS lebih layak untuk digunakan, hal ini karena dalam hasil analisis data menunjukkan bahwa nilai R square tertinggi yaitu model PLS, serta dalam model PLS membuktikan nilai signifikan variabel lebih banyak dari pada model FE dan RE. oleh karena itu peneliti menggunakan hasil regresi data panel PLS untuk menjawab hipotesis dan tujuan penelitian. 
Tabel 4. Data Panel Regression

\begin{tabular}{|c|c|c|c|c|c|c|c|c|c|}
\hline \multirow[t]{3}{*}{ Variabel } & \multicolumn{9}{|c|}{ ROA } \\
\hline & \multicolumn{3}{|c|}{ PLS } & \multicolumn{3}{|c|}{ FE } & \multicolumn{3}{|c|}{ RE } \\
\hline & Coef. & $t$ & $\mathrm{P}>\mathrm{t}$ & Coef. & $t$ & $\mathrm{P}>\mathrm{t}$ & Coef. & $\mathrm{z}$ & $\mathrm{P}>\mathrm{Z}$ \\
\hline BLAUDKO & -0.016 & - & 0.611 & -0.034 & - & 0.401 & -0.015 & - & 0.651 \\
\hline M & & 0.51 & & & 0.84 & & & 0.45 & \\
\hline BLAUDDI & -0.049 & - & 0.095 & -0.020 & - & 0.658 & -0.014 & - & 0.679 \\
\hline $\mathrm{R}$ & & 1.68 & * & & 0.44 & & & 0.41 & \\
\hline SIZE & 0.007 & 1.71 & 0.089 & -0.049 & - & 0.025 & 0.000 & 0.10 & 0.924 \\
\hline ID & 0.131 & 2.28 & $\begin{array}{r}\text { * } \\
0.024 \\
* *\end{array}$ & 0.025 & $\begin{array}{l}2.28 \\
0.26\end{array}$ & $\begin{array}{r}* * \\
0.799\end{array}$ & $\begin{array}{r}7 \\
0.071\end{array}$ & 0.96 & 0.336 \\
\hline _Cosn & -0.190 & 1.36 & 0.176 & 1.501 & 2.34 & $\begin{array}{r}0.022 \\
* *\end{array}$ & 0.022 & 0.10 & 0.923 \\
\hline $\mathrm{N}$ & 120 & & & 120 & & & 120 & & \\
\hline R squared & 0.0716 & & & 0.005 & & & 0.045 & & \\
\hline $\mathrm{F}$ & $\begin{array}{l}0.0000^{* *} \\
*\end{array}$ & & & $\begin{array}{l}0.000^{* *} \\
*\end{array}$ & & & & & \\
\hline $\begin{array}{l}\text { Year } \\
\text { Dummies }\end{array}$ & Include & & & & & & & & \\
\hline
\end{tabular}

Sumber: Data Penelitian, 2020

$p$-values in parentheses ${ }^{*} \mathrm{p}<0.1,{ }^{* *} \mathrm{p}<0.05,{ }^{* * *} \mathrm{p}<0.01$

Berdasarkan hasil analisis regresi data panel dengan model PLS, persamaan regresi untuk penelitian ini adalah sebagai berikut.

ROA $=-0.1900087-0.0163918$ BLAUDKOMit -0.0499854 BLAUDIRit + 0.007985SIZEit + 0.1316262IDit + cit

Berdasarkan model regresi, dapat diartikan bahwa nilai konstan 0,176 menunjukkan bahwa variabel keberagaman gender dewan komisaris (X1), keberagaman gender dewan direksi (X2), ukuran perusahaan (X3), dan direktur independen (X4) memiliki makna yang konstan, sehingga kinerja perusahaan (Y) memiliki nilai negatif 0,1900087. Koefisien regresi variabel BLAUDKOM sebesar 0,0163918 menyatakan jika variabel keberagaman gender dewan komisaris berkurang sebesar satu unit dengan asumsi variabel lain sudah diperbaiki maka variabel kinerja perusahaan meningkat sebesar 0,0163918. Koefisien regresi variabel BLAUDDIR sebesar 0,0499854 menyatakan jika variabel keberagaman gender dewan direksi berkurang sebesar satu unit dengan asumsi variabel lan sudah diperbaiki maka variabel kinerja perusahaan meningkat sebesar 0,0499854.

Koefisien regresi variabel SIZE sebesar 0,0079856 menyatakan jika variabel ukuran perusahaan meningkat sebesar satu unit dengan asumsi variabel lain sudah diperbaiki maka variabel kinerja perusahaan meningkat sebesar 0,0079856 . Koefisien regresi variabel ID sebesar 0,1316262 menyatakan jika variabel direktur independen meningkat satu unit dengan asumsi variabel lain sudah diperbaiki maka variabel kinerja perusahaan meningkat sebesar 0,1316262. Hasil penelitian ini menunjukkan bahwa nilai $\mathrm{R}$ square sebesar 0,0716. Hal ini menunjukkan bahwa variabel kinerja perusahaan dapat dijelaskan oleh variabel keberagaman gender dewan komisaris, keberagaman gender dewan direksi, ukuran perusahaan, dan direktur independen sebesar 7,16\% dan sisanya dijelaskan oleh variabel lain diluar penelitian. Nilai signifikan F sebesar 0,0000 
kurang dari 0,05, hal ini menunjukkan bahwa variabel keberagaman gender dewan komisaris, keberagaman gender dewan direksi, ukuran perusahaan, dan direktur independen secara bersama-sama memiliki pengaruh yang signifikan terhadap variabel kinerja perusahaan.

Analisis regresi menunjukkan bahwa variabel BLAUDKOM memiliki nilai signifikan 0,611 dengan statistik $\mathrm{t}$ negatif. Variabel BLAUDDIR memiliki nilai signifikan 0,095 ( $\mathrm{p}$-value $<0,1$ ) dengan statistik $\mathrm{t}$ negatif. Ini membuktikan bahwa variabel keberagaman gender dewan komisaris tidak berpengaruh signifikan dan negatif terhadap kinerja perusahaan, sedangkan variabel keberagaman gender dewan direksi berpengaruh signifikan dan negatif terhadap kinerja perusahaan. Beberapa variabel kontrol menunjukkan hasil yang signifikan. Variabel SIZE memiliki nilai signifikan 0,089 (p-value $<0,1)$. Variabel ID memiliki nilai signifikan 0,024 (p-value <0,05).

Hasil penelitian menunjukkan bahwa keberagaman gender dewan komisaris tidak berpengaruh positif terhadap kinerja perusahaan $\left(\mathrm{H}_{1}\right.$ ditolak) sedangkan keberagaman gender dewan direksi berpengaruh negatif terhadap kinerja perusahaan $\left(\mathrm{H}_{2}\right.$ ditolak). Hal ini menunjukkan bahwa dengan adanya keberagaman serta keberadaan wanita dalam dewan komisaris maupun dewan direksi tidak memberikan dampak yang positif terhadap kinerja perusahaan. Hasil penelitian ini konsisten dengan penelitian yang dilakukan oleh (Abdullah, 2014), (Chapple \& Humphrey, 2014), (Ionascu et al., 2018) dan (Rafinda et al., 2017) yang menemukan bahwa keberagaman gender tidak menjadi patokan dalam menghasilkan kinerja perusahaan yang baik.

Keberagaman gender dalam perusahaan sendiri di Indonesia saat ini belum diatur dalam regulasi yang dapat menentukan berapa persen kedudukan wanita dalam manajemen puncak perusahaan. Untuk mencapai keberagaman yang baik dalam perusahaan, maka jumlah wanita dan pria harus seimbang tidak boleh lebih atau kurang satu sama lain. Dalam perusahaan yang diteliti oleh peneliti tidak semua perusahaan memiliki anggota wanita maupun pria yang seimbang dalam manajemen puncak, ada yang lebih dan ada yang kurang, karena seperti yang sudah dijelaskansebelumnya bahwa dengan adanya keberagaman gender ini dapat menyeimbangkan sifat-sifat wanita maupun pria yang merugikan perusahaan, sehingga jikalau lebih dominan pria juga tidak baik dan lebih dominan wanita juga tidak baik, karena masing-masing memiliki kelemahan yang dapat merugikan perusahaan (Abdullah, 2014), (Chapple \& Humphrey, 2014), (Dieleman et al., 2015), (Ionascu et al., 2018), dan (Rafinda et al., 2017).

Penelitian ini juga menunjukkan hasil variabel kontrol yang konsisten dengan penelitian sebelumnya. Variabel ukuran perusahaan serta direksi independen berpengaruh terhadap kinerja perusahaan (Ionascu et al., 2018), (Li \& Chen, 2018), (Lückerath-Rovers, 2013), (Novilia \& Nugroho, 2016), dan (Terjesen et al., 2016).

\section{SIMPULAN}

Penelitian ini dilakukan untuk melihat apakah keberagaman gender berpengaruh positif terhadap kinerja perusahaan atau tidak. Populasi dalam penelitian ini yaitu perusahan yang terdaftar di Bursa Efek Indonesia tahun 2015- 
2018 dengan sampel perusahaan property dan perusahaan kesehatan. Metode penelitian ini yaitu penelitian kuantitatif dengan menggunakan STATA sebagai alat ukur. Analisis data menggunakan regresi panel.

Berdasarkan hasil penelitian menunjukkan bahwa kebergaman gender dalam dewan komisaris tidak berpengaruh positif terhadap kinerja perusahaan sedangkan keberagaman gender dewan direksi berpengaruh negatif terhadap kinerja perusahaan. Hal ini menunjukkan bahwa dalam perusahaan keberagaman gender sendiri tidak menjadi patokan perusahaan bisa mencapai kinerja perusahaan yang baik, ada atau tidaknya keberagaman gender dalam dewan perusahaan tidak bisa menjadi tolak ukur keberhasilan perusahaan. Kinerja yang baik bisa di dapatkan dengan kemampuan dari para anggota dewan dalam mengelola perusahaan itu sendiri.

Keterbatasan dalam penelitian ini yaitu peneliti hanya menggunakan dua sector dalam penelitian yaitu perusahan property dan kesehatan. Berikutnya penelti hanya menggunakan satu metode pengukuran keberagaman gender, dan yang terakhr tahun penelitian tergolong singkat hanya 4 tahun. Untuk penelitian selanjutnya disarankan menggunakan dua metode sekaligus untuk mengukur keberagaman gender dalam penelitian yaitu dengan menggunakan dummy dan blau index, proporsi wanita dan blau index, atau bisa menggunakan ketiga metode tersebut dalam satu penelitian, sehingga hasilnya dapat dibandingkan. Kemudian terkait data penelitian kedepannya disarankan lebih diperbanyak data penelitian yang akan digunakan serta tahun penelitian juga di tambah lagi.

\section{REFERENSI}

Abdullah, S. N. (2014). The causes of gender diversity in Malaysian large firms. Journal of Management and Governance, 18(4), 1137-1159. https:// doi.org/10.1007/s10997-013-9279-0

Bart, C., \& McQueen, G. (2013). Why women make better directors. International Journal of Business Governance and Ethics, 8(1), 93. https:// doi.org/10.1504/IJBGE.2013.052743

Carter, D. A., D'Souza, F., Simkins, B. J., \& Simpson, W. G. (2010). The gender and ethnic diversity of US boards and board committees and firm financial performance. Corporate Governance: An International Review, 18(5), 396-414. https:// doi.org/10.1111/j.1467-8683.2010.00809.x

Chapple, L., \& Humphrey, J. E. (2014). Does board gender diversity have a financial impact? Evidence using stock portfolio performance. Journal of Business Ethics, 122(4), 709-723. https:/ / doi.org/10.1007/s10551-013-1785-0

Darmadi, S. (2011). Board diversity and firm performance: The indonesian evidence. Corporate Ownership and Control, 9(1 F), 524-539.

Dieleman, D. M., Ibrahim, M., \& Khor, J. (2016). Building Board Diversity in Asia Pacific. 13(263), 1. https:/ / doi.org/10.1097/00001756-200207190-00002

Dieleman, D. M., Qian, D. M., Ibrahim, M. M., \& Lim, D. V. (2015). Gender Diversity in Asia Pacific: Little of a Good Thing.

Fathonah, A. N. (2018). Pengaruh Gender Diversity dan Age Diversity Terhadap Kinerja Keuangan. 6(3), 373-380.

Hamdani, Y., \& Hatane, S. E. (2015). Pengaruh Wanita Dewan Direksi terhadap Firm Value melalui Firm Performance sebagai Variabel Intervening. 121-132. 
Ionascu, M., Ionascu, I., Sacarin, M., \& Minu, M. (2018). Women on boards and financial performance: Evidence from a European emerging market. Sustainability (Switzerland), 10(5). https:/ / doi.org/10.3390/su10051644

Isidro, H., \& Sobral, M. (2015). The Effects of Women on Corporate Boards on Firm Value, Financial Performance, and Ethical and Social Compliance. Journal of Business Ethics, 132(1), 1-19. https:// doi.org/10.1007/s10551-0142302-9

Isti, Z., \& Adhariani, R. D. (2017). Semakin Beragam Semakin Baik? Isu Keberagaman Gender, Keuangan, Dan Investasi Perusahaan. Nationally Accredited, 21(1040), 1-13. Retrieved from http://jurnal.unmer.ac.id/index.php/jkdp

Jensen, C., \& Meckling, H. (1976). THEORY OF THE FIRM: MANAGERIAL BEHAVIOR , AGENCY COSTS AND OWNERSHIP STRUCTURE I . Introduction and summary In this paper WC draw on recent progress in the theory of ( 1 ) property rights, firm. In addition to tying together elements of the theory of e. 3, 305-360.

Kılıc, M., \& Kuzey, C. (2016). The effect of board gender diversity on firm performance: evidence from Turkey. Gender in Management, 31(7), 434-455. https:/ / doi.org/10.1108/GM-10-2015-0088

Li, H., \& Chen, P. (2018). Board gender diversity and firm performance: The moderating role of firm size. Business Ethics, 27(4), 294-308. https:// doi.org/10.1111/beer.12188

Low, D. C. M., Roberts, H., \& Whiting, R. H. (2015). Board gender diversity and firm performance: Empirical evidence from Hong Kong, South Korea, Malaysia and Singapore. Pacific Basin Finance Journal, 35, 381-401. https:/ / doi.org/10.1016/j.pacfin.2015.02.008

Luckerath-Rovers, M. (2013). Women on boards and firm performance. Journal of Management and Governance, 17(2), 491-509. https:// doi.org/10.1007/s10997-011-9186-1

Lückerath-Rovers, M. (2013). Women on boards and firm performance. Journal of Management and Governance, 17(2), 491-509. https:// doi.org/10.1007/s10997-011-9186-1

Mensi-Klarbach, H. (2014). Gender in top management research: Towards a comprehensive research framework. Management Research Review, 37(6), 538552. https:// doi.org/10.1108/MRR-03-2013-0066

Novilia, O., \& Nugroho, P. I. (2016). Pengaruh Manajemen Puncak Wanita Terhadap Manajemen Laba. Dinamika Akuntansi, Keuangan Dan Perbankan, 5(1), 27-45.

Pasaribu, P. (2019). Gender Diversity in the Boardroom: Evidence from Indonesia Listed Firms Gender Diversity in the Boardroom: Evidence from Indonesia Listed Firms. (January). https:/ / doi.org/10.13140/RG.2.2.30230.60480

Rafinda, A., Rafinda, A., Witiastuti, R. S., Suroso, A., \& Trinugroho, I. (2017). Board Diversity, Risk And Sustainability Of Bank Performance: Evidence From India. (May 1977).

Ramadhani, Z. I., \& Adhariani, D. (2015). Pengaruh Keberagaman Gender Terhadap Kinerja Keuangan Perusahaan dan Efisiensi Investasi. Simposium Nasional Akuntansi XVIII. 
Rose, C. (2007). Does female board representation influence firm performance? The Danish evidence. Corporate Governance: An International Review, 15(2), 404-413. https:/ / doi.org/10.1111/j.1467-8683.2007.00570.x

Shogren, K. A., Wehmeyer, M. L., \& Palmer, S. B. (2017). Causal agency theory. In Development of self-determination through the life-course (pp. 55-67). Springer.

Sial, M., Zheng, C., Cherian, J., Gulzar, M. A., Thu, P., Khan, T., \& Khuong, N. (2018). Does Corporate Social Responsibility Mediate the Relation between Boardroom Gender Diversity and Firm Performance of Chinese Listed $\begin{array}{lll}\text { Companies? } & \text { Sustainability, } & 3591 .\end{array}$ https://doi.org/10.3390/su10103591

Sugiyono, M. (2014). Educational Research Methods Quantitative, Qualitative Approach and R\&D. In Bandung: Alfabeta.

Terjesen, S., Couto, E. B., \& Francisco, P. M. (2016). Does the presence of independent and female directors impact firm performance? A multicountry study of board diversity. Journal of Management and Governance, 20(3), 447-483. https:/ / doi.org/10.1007/s10997-014-9307-8

Wahid, A. S. (2018). The Effects and the Mechanisms of Board Gender Diversity: Evidence from Financial Manipulation. Journal of Business Ethics, (0123456789), 1-21. https:// doi.org/10.1007/s10551-018-3785-6

Wiley, C., \& Monllor-Tormos, M. (2018). Board Gender Diversity in the STEM\&F Sectors: The Critical Mass Required to Drive Firm Performance. Journal of Leadership and Organizational Studies, 25(3), 290-308. https://doi.org/10.1177/1548051817750535 